\title{
MODELLING OF THE QUALITY MANAGEMENT OF THE HUMAN RESOURCE TRAINING
}

\author{
Amelia BUCUR \\ amelia.bucur@ulbsibiu.ro \\ “LUCIAN BLAGA" UNIVERSITY OF SIBIU, SIBIU, ROMANIA
}

\section{ABSTRACT}

It is known that for the scientific substantiation of quality management have been applied models that pertain to mathematical statistics, the probability theory, the information theory, fuzzy systems, graphic methods, time series, and algebraic and numerical methods.

The models are designed to identify certain flaws and to prevent failures, but also to develop goals based on the implementation of the proposed solutions.

The models are recommendations for the identification of opportunities to improve the quality management of human resource training and to make changes in the attitudes and actions performed by the management of organizations.

This paper sets forth a new result that use the concept of global indicator.

\section{Keywords}

Modelling; quality management; indicator; human resource training

\section{Introduction}

Over the years, the mathematical model proved to be a tool for the scientific research of the world, a tool for the close analysis of reality, by means of which the experts were able to assess the consistency of various scientific ideas and theories, in order to find explanations, new concepts, and new relations between phenomena, processes, and activities pertaining to the social and human environment.

Nowadays, modelling and simulation, as methods of scientific and practical approach to the surrounding world, have become an objective necessity, becoming a strong requirement to make use of rigor and abstractization in analyzing the essence and the laws governing real world phenomena.
In the evolution of the human society, mathematics has been the basic tool for solving issues related to human survival and development, as it can define and make available to the human thinking the rules and the explanations for the changes in the surrounding world, in order to assure a continuous adjustment and development of the individual in the economical and social environment etc.

The mathematical model is demanded by the constantly increasing requirements of the human society development, of improving knowledge, of the human capital and the human resource quality, of competitiveness, of aiming to make the modern organizations more effective in the process of product manufacturing and modernization of services in a rapidly-changing world. 
It is known that for the scientific substantiation of quality there have been applied models that pertain to mathematical statistics (e.g. Isaic-Maniu and Vodă 2008), the probability theory (e.g. Kifor and Oprean 2006, Tîţu and Bucur 2015), the information theory (e.g. Dinu 2007), fuzzy systems (e.g. Gogoncea 2007, Marasini et al. 2015), graphic methods (e.g. Isaic-Maniu and Vodă 2006), time series (e.g. Boşcaiu and Vodă 2008), and algebraic and numerical methods (e.g. Bucur 2014 and 2015, Damasio da Silva et al. 2014, Militaru 2008, Oprean and Bucur 2013, 2015, Petrescu and Vodă 2009, Țîţu and Bucur 2015, Vodă 2008, Neelaveni et al. 2015).

In this context, I considered both mathematical modelling of the quality of human resource training as being methods and techniques of practical and theoretical scientific approach, which lead to a better understanding of the place and the role of quality in this field, as well as the sustainable development of quality by providing new practical solutions in order to obtain proper quality that is always superior to the one obtained previously in the field of quality research and analysis.

\section{Modelling of the Quality Management of the Human Resource Training}

The training of the human resources is a continuous, lifelong process by means of which each individual's knowledge and skills are maintained updated by acquiring new general knowledge, basic for the human resource's specialty, in accordance with the constantly increasing organizational needs in a world of globalization, and changes that cannot be stopped.

The training and improvement of the human resource, also referred to as specialized vocational training, implies a real symbiosis between the actual learning process and the application in the practical work of the skills acquired.

Any type of training, either basic or continuous, has beneficial effects both for the organization and for the human resource, if it takes place in the context of the evolution of the requirements expressed by the modern organization and of participants' professional motivations of being trained for a continuously demanding business environment.

Nowadays, in a knowledge society and a learning organization, the continuous training of the human resource represents a new challenge, where the following processes are decisive ${ }^{1}$ : innovation (creating new knowledge); learning (assimilating new knowledge); partnership-based interactivity (related to knowledge).

For this purpose, we consider that the modelling of the quality management of the human resource training represent good steps towards an effective action in the process of designing, implementing and assessing the educational and training programs, of better and more rigorously understanding the fields of competence demanded by the knowledge society: general skills; specific skills; communication skills; management and organizational skills etc.

The rapid development of the occupational standard may lead to the realization of flexible training projects that are useful to human resources and to organizations, as well as encourage the organizational management to create projects, to implement and monitor the training policies, as well as to promote new methods of modelling and simulation in the field of quality management of human resource training.

Seen from this perspective, the quality management of the human resource training, by using some quantitative methods of examination, measurement and assessment of the whole continuing training process of the human resource, becomes a strong requirement, current and of future necessity to modern organizations.

\section{Mathematical Model of the Quality Management of Human Resource Training}

Figure no. 1 displays a descriptive model of the quality management of human resource training, which shall subsequently be translated into an algebraic model, while the evaluation of each stage may be analyzed by using fuzzy methods. 


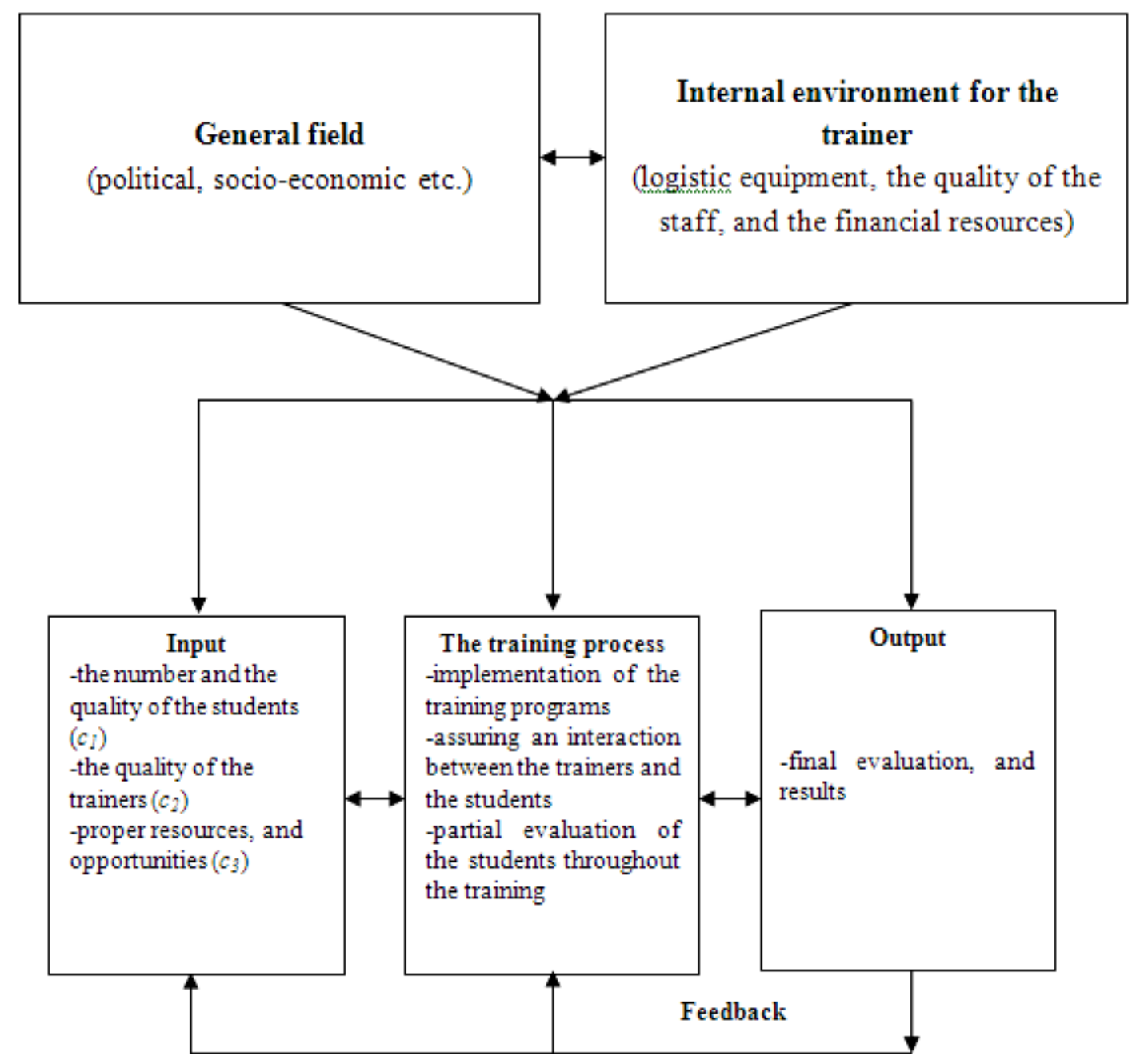

Figure no. 1 Model of the quality of human resource training process (Bucur 2014)

The schematic model is composed of several elements that are closely correlated and interdependent. According to the model, the quality management of the human resource training is comprised of different stages, within which are also established quality criteria (Laurens, 1998), as follows:

Stage I. Establishing the purpose and the requirements of the training

The requirements and the purpose of the training are determined by taking into consideration the real needs of training, arisen from the needs of the labour market and of the individual expectations of the participants. The purpose of the training always consists of meeting the needs and requirements of the participants in the training process, materialized in the quality of the professional knowledge, occupational skills, attitudes, competences and skills necessary to the type of professional activity expected.

The goals of any training activity should be realistic, specific, legible, reliable, coherent, to comply with the needs of the labour market, to be achievable, etc.

\section{Stage II. Writing the syllabus}

The content of the syllabus has to be written so as to include all the elements established by the human resource training policies and strategies specific to each organization.

\section{Stage III. Time, training methods, and logistics}

Each organization sets a short/medium/ long-term schedule of the training course, generally designed as a general system 
specific to human resource training, in order to fulfil the objectives and their personal scope of business.

In order to achieve the goals set within the general plan of training, there are established training and specialized syllabi, or training modules with topics that correspond to the needs existing at a certain moment in the organizational life.

In this case, the main goal is to synchronize the needs of adjusting the training process to the specific and long-term requirements of the general and additional goals of each organization. Training may be provided at the workplace by internal or external trainers, or within specialized educational institutions etc.

The management of the organization, together with the trainer, will establish and provide the necessary logistics, including the methodological instruments of the training that are needed in order to carry out the educational process.

\section{Stage IV. Conducting the training program}

This activity has to be carried out in an interactive and applicative manner, by involving all the participants in the training process in order to achieve the goals of the training.

Stage V. Results, assessment, monitoring, and continuous improvement of the human resource training

The participants will be evaluated both during, as well as at the end of the training process, when there will be a final evaluation in order to quantify the results obtained in the achievement of the training goals.

The focus should especially be on analyzing the training quality indicators set by the management of the organization, rendered by meeting the requirements and goals of the training, of the practical and theoretical skills acquired by each student, but also of the quality of the results of the actual training process, and of the results obtained in the labour process by the students, during the period immediately following the training course.

The quality of human resource training improves permanently by post-training monitoring and assessments in order to ensure that the human resource acquires new abilities in a world of changes to which each organization has to adjust in order to survive and modernize.

The quality indicators of the human resource training will express the degree of assimilation of the professional and theoretical knowledge, the skills, and the attitudes of the students after having graduated the training course.

Considering the theoretical elements of the model and the relations and interdependences between them, the mathematical model pertaining to the quality management of human resource training may be formulated as a mathematical expression conveyed in formula (1).

$$
\begin{gathered}
/=\mathrm{p}_{1} / 1+\mathrm{p}_{2} / 2+\mathrm{p}_{3} / \mathrm{H}^{+}+\mathrm{p}_{4} / 4+\mathrm{p}_{\mathrm{S}} / \mathrm{s} \\
\mathrm{p}_{1}+\mathrm{p}_{2}+\cdot+\mathrm{p}_{\mathrm{S}}=1, \mathrm{p}_{1}, \mathrm{p}_{2}, \ldots, \mathrm{p}_{\mathrm{S}} \diamond 0
\end{gathered}
$$

The mathematical expression of the model represents a weighted means, as a global indicator, obtained based on the linear combination of the quality levels $/ 1, / 2, / 3, / 4, / s$, resulted from each stage of the model, as follows:

\section{Stage $I$.}

$/ 1=/ 1\left(i_{1}, \ldots, i_{n}\right)$ quality indicator of the policies, requirements, and of the goal of the training; $\mathrm{i}_{1}, \ldots, \mathrm{i}_{\mathrm{n}}=$ quality level of organizationalgoals;

\section{Stage II.}

$/ 2=/ 2\left(i_{n+1}, \ldots, i_{m},\right)$ quality indicator of the training program project; $i_{n+1}, \ldots, i_{m}=$ output (results) of stage I;

\section{Stage III.}

$/_{3}=/{ }_{3}\left(i_{m+1}, \ldots, i_{p}\right)$ quality indicator of the implementation stage; $\mathrm{i}_{\mathrm{m}+1}, \ldots, \mathrm{i}_{\mathrm{p}}=$ output (results) of stage II;

\section{Stage IV.}

$/ 4=/ 4\left(i_{p+1}, \ldots, i_{s}\right)$ quality indicator of the evaluations made during the training; $\mathrm{i}_{\mathrm{p}+1}, \ldots, \mathrm{i}_{\mathrm{s}}=$ output (results) of stage III; 


\section{Stage V.}

$/ s=/ s\left(i_{s+1}, \ldots, i_{r}, o_{c+1}, \ldots, o_{d}\right)$ quality indicator of the final results; $\mathrm{i}_{\mathrm{s}+1}, \ldots, \mathrm{i}_{\mathrm{r}}=$ outputs (results) of stage IV;

$p_{1, \ldots,} p_{5}$ represent weights or influence factors defined by the management of the organization in case of a simulation, or real factors resulted from scientific findings.

\section{Conclusions}

Considering the complexity of the processes from the real world, as well as the mathematical limitations known at present, no matter the mathematical model used or designed, it has an idealized feature and displays only a part of the properties of he quality system.

Most experts in the field of model design and application by using the mathematical tools and the software support an important idea, for the future, an idea that I support, namely that a system of models (SM) should be created in order to wholly comprise the reality that needs to be modelled.

Considering these terms, the tendency noticed at the present time regarding the extension of research in the field of artificial intelligence is highly important. Thus, the fields of use of the heuristic algorithms and methods shall be extended, as they are more 'flexible' and may be adjusted to the rigor of mathematical modelling and simulation in order to solve issues related to quality.

The models are designed to identify certain flaws and to prevent failures, but also to develop goals based on the implementation of the proposed solutions.

The models are recommendations for the identification of opportunities to improve the quality management of human resource training and to make changes in the attitudes and actions performed by the management of organizations.

In formula (1), I created a mathematical model for a global indicator of the quality management of human resource training. In order to simulate and forecast its growth during fixed periods of time, one may use the Forecasting module of the WinQSB software or other software specialized in forecasting. Moreover, by using software such as SPSS, one may analyze the interdependencies between the indicator created in (1) of this paper and different indicators specific to the goals set by the organizations for various periods of time.

\section{Acknowledgement}

Project financed from Lucian Blaga University of Sibiu research grants LBUS-IRG-2015-01.

\section{Bibliography}

Isaic-Maniu, Al. and Vodă V.Ghe.,"Aplicaţii ale repartiţiei Poisson în managementul calităţii”, Revista Calitate şi Management, Issue 1, (2008): 44-47

Kifor, C.V. and Oprean, C., "Ingineria calităţii. Îmbunăţăţirea 6 Sigma", (Sibiu: Editura Universităţii „Lucian Blaga” din Sibiu, 2006)

Tîţu, A.M. and Bucur, A, "Models for Quality Analysis of Services in the Local Public Administration", Quality \& Quantity, (2015). doi. 10.1007/s11135-015-0183-3

Dinu, Ghe. and Vodă, V.Ghe., "Despre informaţie, entropie şi aplicaţii în managementul calităţii(I)", Revista Calitatea-acces la succes, Issue3, (2007): 59-60

Gogoncea, D.: "Aplicarea sistemelor fuzzy în dinamica proceselor globale de standardizare în managementul calităţii”, Revista Calitatea-acces la succes, 8(9), (2007): 59-62

Marasini, D., Quatto, P., Ripamonti, E.: Intuitionistic fuzzy sets in questionnaire analysis. Quality \& Quantity (2015). doi: 10.1007/s11135-015-0175-3 
Isaic-Maniu, Al. and Vodă V.Ghe.,"Metode grafice în calitologie”, Revista Calitatea-acces la succes, 6, (2006): 58-60

Boşcaiu, V. and Vodă, V.Gh., "Aplicaţii ale seriilor de timp vectoriale în controlul calităţiii”, Revista Calitate şi Management, 11, (2008): 46-47

Bucur, A., Modelare şi simulare cu privire la calitate şi managementul calităţii, (Sibiu: Editura Universităţii „Lucian Blaga” din Sibiu, 2014)

Bucur, A., Contribuţii la abordarea ştiinţifică a calităţii şi managementului calităţii, prin modelare şi simulare, (Sibiu: Editura Universităţii „Lucian Blaga” din Sibiu, 2015)

Damasio da Silva, C.F., Batista, D.A. and Dumke de Medeiros, D.: "A proposed method to evaluated the quality of services using Fuzzy set theory", Quality \& Quantity 48(2), (2014): 871-885

Militaru, C., "Teoria regresiei ca instrument de predicţie în managementul calităţii", Revista Calitate şi Management, 6, (2008): 44-47

Oprean, C. and Bucur, A., "Modeling and simulation of the quality's entropy", Quality and Quantity, Vol.47, Issue 6, (2013): 3403-3409

Oprean, C. and Bucur, A., "Modeling the quality entropy of key programs of study",Quality and Quantity, Vol.49, Issue 2, (2015): 631-636

Petrescu, E., Vodă G.V., "Legea numerelor mici în studiul calităţii produselor", Revista Calitatea-acces la succes, Vol.10, Issue 6, (2009): 59-63

Vodă, G.V., "Dezvoltarea ideii de corelaţie. Aplicaţii", Revista Calitatea-acces la succes, Vol. 9, Issue 12, (2008): 59-62

Neelaveni, C. and Manimaran, S., "Structural equation modelling for analysing the impact of quality of administrative practices in higher educational institutions", Quality \& Quantity (2015). doi: 10.1007/s11135-015-0227-8

Rossi, F. and Rosli, A., "Indicators of University - Industry Knowledge Transfer Performance and Their Implications for Universities: Evidence From the United Kingdom", Studies in Higher Education, Vol. 40, Issue 10, (2015): 1970-1991. 